\title{
OPTIMALISASI POTENSI INDUSTRI HALAL DI INDONESIA MELALUI PERAN PASAR MODAL SYARIAH
}

\author{
Melisa1, Lailatul Khikmawati2 \\ 1,2)IAIN Pekalongan \\ 1)1118266melisa@gmail.com, ${ }^{2)} \underline{\text { lailatulkhikmawati746@gmail.com }}$
}

\begin{abstract}
Abstrak. Trend halal di Indonesia semakin diminat masyarakat. Potensi industri halal di Indonesia juga berkembang pesat. Industri tersebut meliputi makanan dan minuman, trend fashion, dan wisata halal. Pengembangan industri tersebut makin nampak dan menunjukkan ke arah yang lebih baik bagi perkembangan perekonomian di Indonesia. Namun, biasanya dari segi pendanaan industri halal sering mengalami permasalahan. Tujuan dari penelitian ini yaitu mengoptimalkan potensi pengembangan industri halal di Indonesia melalui pendanaan yang dilakukan pasar modal syariah. BEI bersinergi bersama dengan OJK untuk mempermudah para pelaku industri halal untuk masuk ke pasar modal syariah dengan berbagai bentuk produk pendanaan yang sedang dikembangkan yaitu IPO, sukuk, dan ECF.
\end{abstract}

Kata Kunci : Industri Halal, Pasar Modal Syariah, IPO, Sukuk, ECF, Papan Akselerasi.

\begin{abstract}
The halal trend in Indonesia is increasingly in demand by the public. The potential of the halal industry in Indonesia is also growing rapidly. These industries include food and beverages, fashion trends, and halal tourism. The industrial development is increasingly visible and points to a better direction for economic development in Indonesia. However, usually in terms of funding the halal industry often experiences problems. The purpose of this research is to optimize the potential for the development of the halal industry in Indonesia through funding by the Islamic capital market. IDX works together with the OJK to make it easier for halal industry players to enter the Islamic capital market with various forms of funding products that are being developed, namely IPO, sukuk, and ECF.
\end{abstract}

Keywords: Halal Industry, Islamic Capital Market, IPO, Sukuk, ECF, Acceleration Board.

\section{PENDAHULUAN}

Seiring berkembangnya zaman trend ekonomi syariah semakin diminati di Indonesia, tidak dipungkiri karena di Indonesia sendiri didominasi mayoritas beragama Islam. Sehingga sebagian besar konsumen tertarik pada produk-produk yang halal. Produk halal merupakan produk yang sesuai dengan syariat Islam, sehingga produsen-produsen halal semakin menggiatkan industri ini. Ada sekitar 1,8 miliar penduduk muslim penduduk muslim menjadi konsumen dalam industri ini. Sehingga peluangnya meningkat sebanyak 5,2\% setiap tahun 
dan pengeluarannya mencapai USD 2,2 Triliun dan akan terus meningkat setiap tahunnya. (STGIR, 2019). Berikut juga data sertifikasi halal oleh MUI yang terus meningkat setiap tahunnya.

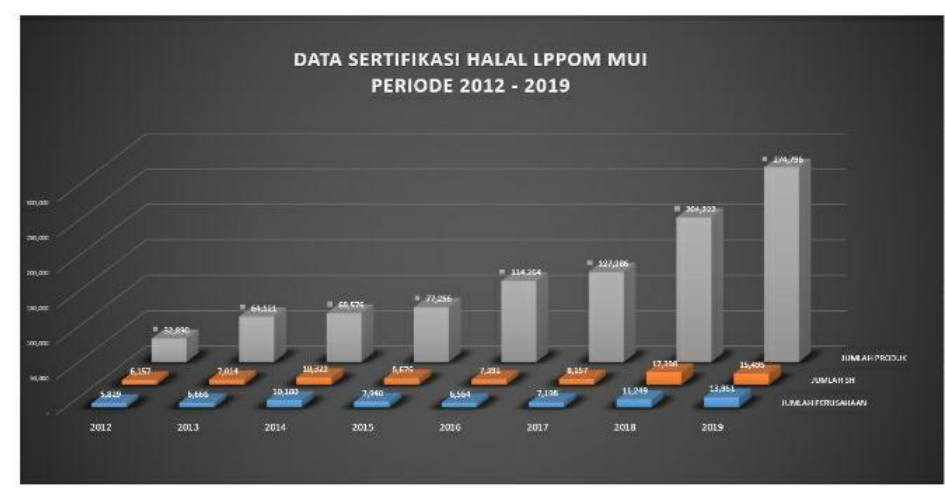

Gambar 1. Data Sertifikasi Halal LPPOM MUI Periode 2012-2019 Sumber : mui.co.id

Pada masa pandemi covid-19 seperti ini supaya bisa bertahan maka para pelaku industri harus membuat produk yang berkualitas, dengan begitu indutri yang dijalankan akan berkembang. Namun untuk mengembangkan industri perlu pendanaan modal yang besar. Terlepas dari itu dalam pengembangan industri memerlukan pengetahuan terkait penyediaan bermacam pendanaan syariah, pembiayaan yang sesuai terhadap karakteristik masing-masing industri. Misalnya, jika pelaku industri ingin memperoleh pendanaan maka akan dibantu melalui pasar modal. Karena peran dari pasar modal sendiri yaitu membantu pendanaan bagi masyarakat yang ingin melakukan kegiatan usaha yang tidak memiliki modal. Dengan begitu pelaku industri akan merasa terbantu.

Pasar modal syariah merupakan kegiatan pasar modal yang tidak bertentangan dengan prinsip syariah. Dalam pasar modal syariah tidak boleh terkandung adanya maysir (perjudian), gharar (ketidakpastian), riba, bathil maupun ikhtikar (penimbunan). Konsep dalam pasar modal ini selaras dengan pengembangan industri halal di Indonesia yaitu penggunaan segala sesuatu yang sesuai dengan prinsip syariah. (Sumber : IDX Syariah)

Produk-produk dalam pasar modal syariah yaitu berupa efek syariah. Pasar modal syariah digunakan sebagai sarana untuk pendanaan usaha untuk mendapat dana dari investor. Dana digunakan untuk pengembangan usaha maupun penambahan modal kerja. Sejalan dengan tersebut harusnya pasar modal syariah dapat menjadi alternatif pendanaan bagi pengembangan industri halal di Indonesia karena akan menjadi investasi yang menarik 


\section{AL-IOTISHOD}

Jurnal Ehonomi Suariah

Institut Agama Islam Sunan Kalijogo Malang P-ISSN 2715-7725 E-ISSN 2721-9496

Volume 3 Nomor 1 Juni 2021

bagi investor ketika investasi bisnis yang dijalankan memadukan aspek bisnis dan spiritual sehingga sesuatu yang dijalankan tersebut bernilai ibadah.

Harapan dari para pelaku industri untuk pasar modal supaya bisa memberikan dampak yang besar bagi industri agar bisa mengekspor produknya ke pasar Internasional. Kegiatan industri berjumlah 64 juta dan 60\% nya mempunyai peran terhadap PDB nasional, 95\% mempunyai peran pada terciptanya suatu lapangan pekerjaan. Dapat kita ketahui, potensi kegiatan industri begitu besar untuk perekonomian nasional karena banyak penduduk indonesia yang sebagian besar bermatapencaharian sebagai pelaku industri.

\section{KAJIAN TEORI}

1. Pasar modal syariah

Pasar modal merupakan suatu kegiatan yang berhubungan dengan perdagangan surat berharga (penawaran efek), perusahaan dan penawaran umum terkait dengan efek yang akan terbit. Menurut Pandji Anoraga, 2008. Maksud dari efek syariah dalam pasar modal yaitu cara penerbitannya, pengelolaan dalam perusahaan dan juga akad yang digunakan harus memenuhi prinsip-prinsip syariat Islam. Efek syariah dan penerapan prinsip syariah dalam pasar modal meliputi reksadana syariah, saham syariah, saham berharga, dan kontrak investasi yang harus dilakukan sesuai dengan prinsip-prinsip syariah ini dimuat dalam Fatwa DSN MUI No.40/DSN-MUI/X/2003.

Pada pasar modal syariah, jika perusahaan berkeinginan memperoleh suatu pembiayaan pada surat berharga, perusahaan harus masuk kriteria syariah. Karena pasar modal syariah berpedoman pada prinsip syariah. Prinsip-prinsip tersebut yaitu:

a. Pasar modal syariah dalam melakukan jual beli saham dll harus sesuai prinsip syariah dan melarang seperti judi, riba, gharar dll.

b. Lembaga yang menerbitkan saham maupun surat berharga dengan efek syariah wajib mematuhi peraturan syariat Islam.

c. Efek syariah harus berupa harta dan tidak boleh menarjetkan keuntungan pada utang piutang perusahaan. ${ }^{1}$

2. Industri produk halal

${ }^{1}$ M. Fauzan, Dedi Suhendro, "Peran Pasar Modal Syariah Dalam Mendorong Laju Pertumbuhan Ekonomi Di Indonesia”, Jurnal Human Falah, Vol. 5, No. 1, Januari-Juni 2018, hlm. 77. 
Produk halal merupakan produk yang telah melewati uji coba sertifikasi halal dan terdapat logo halal di makanan, minuman, kosmetik, obat, dan produk yang diapakai oleh manusia. Apabila barang yang diproduksi telah melewati prinsip syariah dan uji coba sertifikasi halal maka barang tersebut siap diterbitkan dan dikonsumsi dengan aman tanpa ada keraguaan.

Dalam menguji coba sertifikasi halal harus ada lembaga yang menjamin kehalalannya. Lembaga tersebut bernama BPJPH (Badan penyelenggara Jaminan Produk halal), badan ini bertugas untuk bertanggung jawab terhadap jaminan suatu produk halal. Namun BPJPH tidak hanya sendiri tetapi juga bekerja sama dengan Lembaga Pemeriksa Halal (LPH) dan juga Majelis Ulama Indonesia (MUI). LPH sendiri bertugas sebagai pemeriksaan produk halal dan yang menetapkan apakah produk itu halal atau tidaknya yaitu MUI. ${ }^{2}$

3. Cara pengajuan dan penetapan kehalalan pada produk

Bagi pengusaha maupun pelaku bisnis dalam pembuatan produk dan dalam pemasaran produk bisa melakukan permohonan kehalalan produk untuk memperoleh sertifikasi halal oleh MUI yaitu dengan cara pertama para pengusaha maupun pelaku ekonomi mengajukan surat permohonan sertifikasi tertulis kepada BPJPH yang kemudian akan diperiksa oleh LPH dan setelah diperiksa akan ditetapkan kehalalan produk oleh MUI. Setelah proses pengajuan permohonan sertifikasi halal berhasil dan hasilnya produk telah mendapatkan sertifikasi halal maka produk siap dipasarkan dan dikonsumsi dengan halal.

\section{METODE PENELITIAN}

Metode yang digunakan dalam penelitian ini yaitu teknik pengumpulan data, teknik studi pustaka, teknik identifikasi masalah, teknik praproses, teknik analisis data dan hasil analisis data dan teknik evaluasi, yang akan dijelaskan sebagai berikut:

1. Teknik pengumpulan data

${ }^{2}$ Nor Aini Haji Idris dan Moh Ali Moh Nur, Analisis Keprihatinan Pengguna Muslim Terhadap Isu Halal-Haram Produk Melalui Pembentukan Indeks, PROSIDING PERKEM VIII, JILID 3 (2013) 1245- 12 ISSN: 2231-962X, Persidangan Kebangsaan Ekonomi Malaysia ke VIII (PERKEM VIII) "Dasar Awam Dalam Era Trnsformasi Ekonomi: Cabaran dan Halatuju” Johor Bahru, 7-9 Juni 2013, hlm.1249. 
Dalam penelitian ini teknik pengumpulan data digunakan untuk mengetahui informasi tentang industri halal di Indonesia melalui peran pasar modal syariah. Pengumpulan data dalam penelitian ini menggunakan teknik wawancara kepada pihak terkait yang melakukan kegiatan industri dan pihak pasar modal syariah.

2. Teknik identifikasi masalah

Teknik identifikasi masalah dilaksanakan seusai seluruh data sudah diperoleh sesuai dengan penelitian ini.

3. Teknik praproses

Teknik praproses dalam penelitian ini untuk menyeleksi data yang diperoleh ketika melakukan penelitian. Teknik proses ini dilakukan untuk memperoleh suatu data yang telah diseleksi dan sudah siap dipakai untuk penelitian ini.

4. Teknik studi pustaka

Teknik studi pustaka dalam penelitian menggunakan beberapa literatur teori yang berfungsi untuk mengetahui teori-teori yang sama dalam penelitian ini.

5. Teknik analisis data dan hasil analisis data

Teknik analisis data berfungsi untuk menganalisis data yang diperoleh pada saat penelitian. Kemudian dari data yang sudah dianalisis akan masuk pada tahap dimana hasil dari analisis data tersebut akan disesuaikan dengan topik yang dibahas dalam penelitian ini.

6. Teknik evaluasi

Pada teknik evaluasi ini digunakan untuk melihat hasil analisis data tadi apakah sama dengan apa yang diharapkan oleh peneliti. Dan juga untuk perbandingan antara analisis data yang diperoleh terhadap hasil data sudah dianalisis tadi. ${ }^{3}$

\section{HASIL PEMBAHASAN}

\section{Potensi industri halal di Indonesia}

Jumlah penduduk muslim yang banyak di Indonesia menyebabkan industri halal memiliki potensi yang besar pula. Potensi itu dapat dilihat dari beberapa sektor makanan dan minuman, fashion, dan pariwisata. Potensi industri halal di Indonesia menempati

\footnotetext{
${ }^{3}$ M. Fauzan, Dedi Suhendro, "Peran Pasar Modal Syariah Dalam Mendorong Laju Pertumbuhan Ekonomi Di Indonesia, Jurnal Human Falah”, Vol.5, No.1, Januari-Juni 2018, hlm.81-82.
} 
posisi pertama dalam pengeluaran untuk makanan halal sebanyak US\$ 170 miliar. Ini menunjukkan potensi industri makanan halal ini bisa brkembang, namun belum dimanfaatkan dengan maksimal. Menurut survei OIC Indonesia masuk ke dalam 5 top Importir Makanan Halal OIC Report 2017.

\section{Gambar 2. Lima Top Importir Makanan Halal OIC Report 2017}

Lima Top Importir Makanan Halal OIC Report 2017

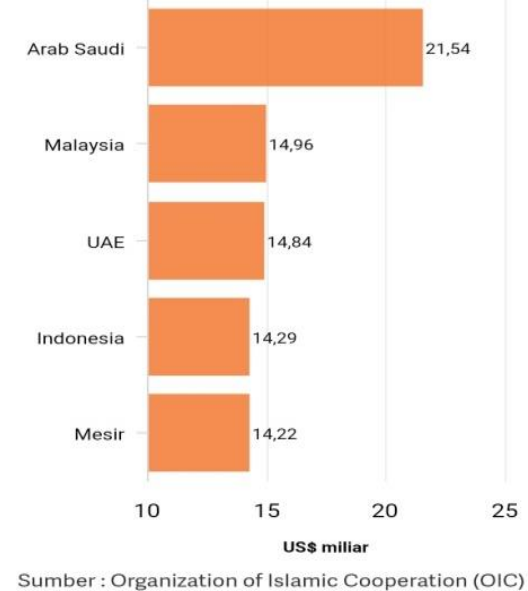

Makanan halal ditafsirkan tidak hanya diperbolehkan, tetapi juga layak dan sehat untuk dikonsumsi. Untuk mayarakat muslim dikenal dengan sertifikasi halal ditandai dengan adanya lambang halal pada kemasan makanan maupun minuman. Bagi muslim, lambang ini menandakan bahwa makanan dan minuman tersebut telah sesuai dengan syariat Islam. Namun, bagi non muslim label ini juga diartikan sebagai kebersihan, dan kelayakan konsumsi dari produk tersebut.

Selain industri makanan industri fashion Indonesia memiliki peluang mengembangkan bisnis fahion dengan konsep busana muslim atau lebih tertutup dan lebih sopan dan tren ini mulai menjadi gaya hidup. Dari tabel dibawah ini dapat dilihat 10 negara tujuan utama ekspor pakaian jadi Indonesia pada tahun 2018 konsumsi ini sudah mencapai Rp 280 Triliun dengan laju pertumbuhannya sekitar 18,2\%. 


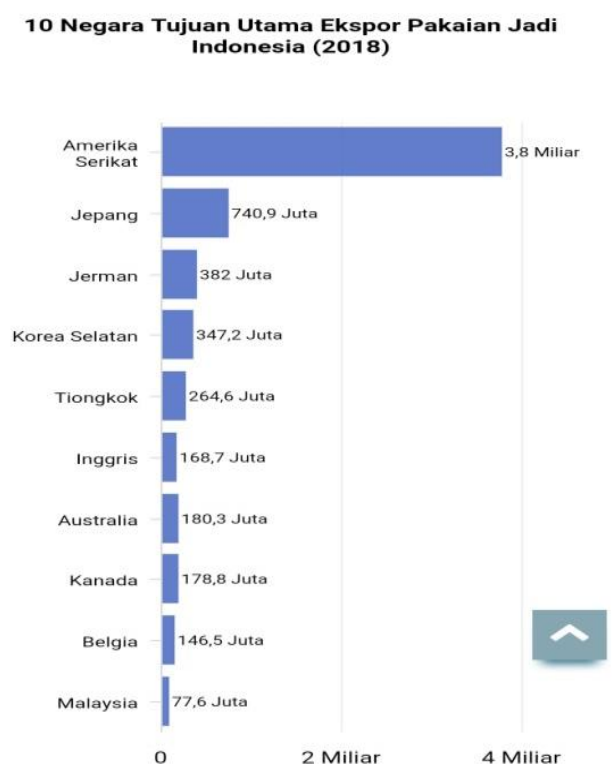

Gambar 3. 10 Negara Tujuan Utama Ekspor Pakaian Jadi Indonesia (2018)

Sumber : Katadata

Sehingga industri ini berpotensi untuk mengalami perkembangan apalagi pasar sekarang menyentuh digitalisasi dan mudah dilaksanakan secara online. Selain industri fashion, industri wisata halal Indonesia dapat meraih title destinasi wisata halal terbaik dunia versi Global Muslim Travel Index (GMTI) pada tahun 2019.

10 Destinasi Wisata Halal Negara OKı

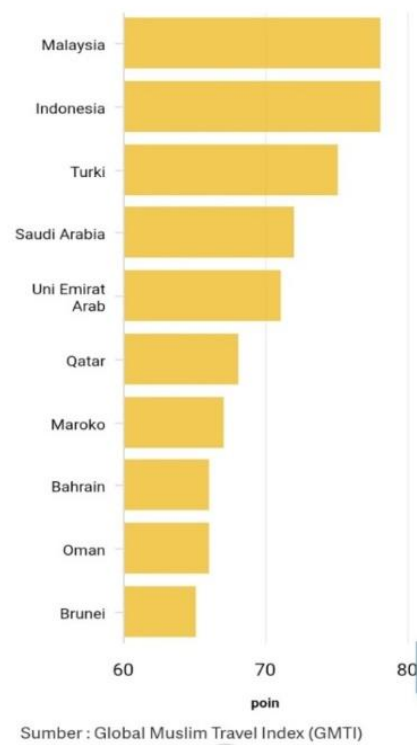

Gambar 4. 10 Destinasi Wisata Halal Negara OKI 


\section{AL-IOTISHOD \\ Jurnal Ehonomi Suariah}

Institut Agama Islam Sunan Kalijogo Malang P-ISSN 2715-7725 E-ISSN 2721-9496

Volume 3 Nomor 1 Juni 2021

Wisata dikategorikan wisata halal ketika lingkungan dan layanannya berbasis agama, yang didalamnya mencakup fasilitas ibadah, makanan halal, tempat wudhu yang memadai, dan tidak termasuk dalam lingkungan islamfobia. Indonesia telah mengembangkan sektor industri halal yang ramah muslim yaitu Aceh, Riau dan Kepulauan Riau, DKI Jakarta, Jawa Tengah, Jawa Timur, Jawa Barat, Sulawesi Selatan, Nusa Tenggara Barat, Sumatera Barat dan Yogyakarta. (Katadata, 2020).

\section{Alternatif pembiayaan industri halal melalui pasar modal syariah}

Pasar modal merupakan sarana yang menghubungkan antara penyedia dana dan yang membutuhkan dana. Tersedia dalam 3 jenis pasar, yaitu pasar primer, sekunder dan paralel. Pasar primer digunakan dimana penjualan efek yang diterbitkan perusahaan langsung melalui bursa efek, sehingga perusahaan menghasilkan dana. Lalu yang kedua pasar sekunder, setelah penjualan pada pasar primer berakhir, maka adanya efek yang listing atau go public, kemudian pada pasar sekunder harga efek ditentukan kurs. Pasar paralel merupakan pasar yang dilaksanakan persatuan perdagangan uang dan efek-efek.

Program jangka panjang Bursa Efek Indonesia (BEI) bersama OJK mempermudah UMKM dan industri halal dalam memasuki pasar modal syariah. Sehingga pasar modal syariah dapat menjadi alternatf solusi pembiayaan pada industri halal di Indonesia. Ada beberapa produk yang ditawarkan pasar modal syariah yang dapat digunakan dalam pengembangan industri halal di Indonesia :

a. IPO (Initial Public Offering)

IPO merupakan sebuah sistem dimana suatu perusahaan menjual atau menawarkan sahamnya ke masyarakat. Ketika menjalankan IPO ini berarti sebuah perusahaan dinyatakan Go Public. Sebenarnya potensi pertumbuhan perekonomian dapat lebih cepat ketika menggunakan IPO ini. Apalagi jika diterapkan dalam industri halal yang sebenarnya sudah mendapat perhatian dari masyarakat. Ketika sudah IPO maka perusahaan yang go public dapat melakukan penerbitan saham atau penerbitan instrumen yang sifatnya utang. Ini dapat menjadi langkah awal industri halal untuk mendapatkan pendanaan dari publik untuk mengembangkan usahanya. Hal ini lebih menarik perhatian investor karena dengan perusahaan itu sudah go publik maka manajemen keuangan maupun manajemen perusahaannya akan transparan dan dipublikasikan. 
b. Sukuk

Sukuk merupakan efek syariah berbentuk sertifikat atau bukti kepemilikan yang memiliki nilai sama tidak terbagi atas aset yang mendasarinya. Sukuk bukan surat utang tetapi suatu aset atau proyek yang dimiliki bersama. Instrumen investasi ini lebih banyak digunakan oleh pemerintah dan masih banyak UMKM yang belum mengetahui tentang sukuk ini. Sukuk atau obligasi syariah menggunakan akad mudharabah dengan sistem bagi hasil. Dimana investor yang sudah mengetahui pendapatan perusahaan yang bergerak dalam bidang industri halal dapat memberikan investasinya untuk perusahaan tersebut. Sukuk ini akan lebih menarik investor karena aman dengan resiko nol karena pembayarannya diterbitkan dan dijamin oleh negara, imbalan yang dibayarkan tetap sehingga memberi kepastian pada pemilik modal dan pajaknya lebih rendah, kemudian dapat diperjualbelikan di pasar sekunder. Hal ini dapat dilakukan untuk sukuk dapat cair sebelum jatuh tempo.

c. Equity Crowfunding (ECF)

ECF ini merupakan mekanisme layanan urun dana melalui penawaran saham berbasis teknologi informasi yang dapat dilakukan di platform online. Kemudian BEI memunculkan papan akselerasi dengan menggalang dana publik mencakup sampai Rp 250 miliar. ECF dan papan akselerasi ini dapat berkolaborasi dalam pasar modal untuk membantu mengembangkan industri halal di Indonesia. Pendanaan di bursa efek seharusnya menarik minat investor karena capital gain yang ringan dan pajak transaksi final hanya 0,1\%. Biasanya investor yang melakukan ECF dalam pasar modal ini sudah berpengalaman dan digunakan untuk investasi jangka panjang. Sehingga industri halal yang siap mendapatkan pendanaan ini harus memiliki arah perusahaan menuju pengembangan dan valuasi perusahaan yang berlipat.

Selain bentuk pembiayaan yang ditawarkan pasar modal syariah, OJK dn BEI mempermudah langkah-langkah UMKM dan industri halal untuk mengakses dana dari pasar modal syariah yaitu dengan menyempurnakan aturan dimana perusahaan dengan asset dibawah 50 miliar dapat mengajukan pembiayaan ini hal ini sangat cocok untuk perusahaan rintisan atau start company. Biaya dapat ditekan karena informasi dan registrasi dapat dilakukan secara online untuk kemudian ditelaah oleh BEI untuk mendapatkan pasar yang tepat. Konsultan hukum tidak wajib ada untuk perusahaan yang baru dirintis yang perlu 
dipatuhi adalah hukum administrasi pajak dan legalitas. Berikut data perusahaan yang telah memanfaatkan pasar modal syariah sebagai alternatif pembiayaan nya.

Tabel 1. Dividen (Yield) Perusahaan Industri Halal Di Indonesia Tahun 2017-2020

\begin{tabular}{|l|c|c|c|c|}
\hline \multicolumn{2}{|c|}{ Nama Perusahaan } & \multicolumn{4}{|c|}{ Dividen (Yield) } \\
\cline { 2 - 6 } & 2017 & 2018 & 2019 & 2020 \\
\hline PT Indofood CBP Sukses & - & 139 & 195 & 215 \\
Makmur Tbk. & & $(1,43 \%)$ & $(2,10 \%)$ & $(2,30 \%)$ \\
\hline $\begin{array}{l}\text { PT Industri Jamu dan Farmasi } \\
\text { Sido Muncul }\end{array}$ & 26 & 29 & - & 26 \\
$(2,95 \%)$ & $(2,51 \%)$ & & $(3,40 \%)$ \\
\hline $\begin{array}{l}\text { PT Garudafood Putra Putri } \\
\text { Jaya Tbk }\end{array}$ & - & - & 17 & 28 \\
$(1,32 \%)$ & & $(2,27 \%)$ \\
\hline
\end{tabular}

Sumber : Data Diolah

Dari tabel diatas dapat disimpulkan bahwa untuk ke tiga perusahaan industri halal yng telah IPO mengalami kenaikan laba secara signifikan. Dividen atau pembagian keuntungan masih tergolong aman PT indofoof CBP Sukses Makmur Tbk IPO pada tahun 1994 dengan pembagian dividen terbesar terjadi pada tahun 2020 sebesar 2,30\%. Untuk PT Sido Muncul IPO pada tahun 2013 dengan pembagian dividen terbesar terjadi pada tahun 2020 sebsar 3,40\%. Untuk PT Garudafood Putra Putri Jaya Tbk IPO pada tahun 2018 dengan pembagian dividen terbesar pada tahun 2020 sebesar 2,27\%. Dari analisis diatas terbukti bahwa optimalisasi potensi industri halal di Indonesia dapat meningkat melalui pembiayaan pasar modal syariah dibuktikan dengan tingkat dividen atau pembagian keuntungan kepada investor yang meningkat setiap tahunnya.

\section{PENUTUP}

Ekonomi syariah menjadi trend center baru bagi perkembangan perekonomian di Indonesia. Salah satunya yaitu pengembangan industri halal yang semakin pesat. Namun, dalam perkembangannya seringkali industri-industri tersebut terkendala terkait dana maupun sumber modal yang dibutuhkan perusahaan. Harapannya kendala tersebut dapat teratasi dan memberi pengaruh yang positif pada pengembangan industri halal yaitu melalui pasar modal syariah. Dalam pembahasan sudah dijelaskan bahwasanya ada beberapa produk dari pasar modal syariah yang dapat dipilih dan digunakan industri halal dalam mendapatkan 
pendanaan yaitu dengan IPO, sukuk, dan ECF. Diharapkan dengan adanya penelitian ini dapat berguna untuk pengembangan industri halal melalui pasar modal syariah kedepannya.

Penulis menyadari bahwa penelitian ini belum sempurna, diharapkan bagi pembaca untuk mencari sumber referensi lain. Dan saran dari penulis yaitu untuk pasar modal syariah agar bisa menindaklanjuti penelitian ini dan mengimplementasikan produk-produk yang telah digagas tersebut. dimana penggunaannya akan sangat bermanfaat bagi UMKM maupun industri-industri halal di Indonesia. 


\section{DAFTAR PUSTAKA} 2021)

Bursa Efek Indonesia. https://www.idx.co.id/idx-syariah/produk-syariah/. (10 Januari

Dedi Suhendro dan M. Fauzan. 2018. "Peran Pasar Modal Syariah Dalam Mendorong Laju Pertumbuhan Ekonomi Di Indonesia”. Jurnal Human Falah.Vol. 5. No. 1. Januari-Juni.

Fathoni, Muhammad Anwar dan Tasya Hadi. 2020. "Potret Industri Halal Indonesia : Peluang dan Tantangan", Jurnal Ilmiah Ekonomi Islam 6 (03)

Irma, Ramadhani. 2017. "Linkage Program dan Pasar Modal Sebagai Alternatif dalam Akses Pendanaan UMKM di Era Masyarakat Ekonomi Asean (MEA)". Jurnal 'Adliya Vol. 11, No. 2.

Katadata.https://katadata.co.id/timpublikasikatadata/analisisdata/5ea3a73811d32/i ndustri-halal-untuk-semua. (10 Januari 2021)

Moh Ali Moh Nur dan Nor Aini Haji Idris. 2013. Analisis Keprihatinan Pengguna Muslim Terhadap Isu Halal-Haram Produk Melalui Pembentukan Indeks. PROSIDING PERKEM VIII, JILID 3 (2013) 1245- 12 ISSN: 2231-962X. Persidangan Kebangsaan Ekonomi Malaysia ke VIII (PERKEM VIII) "Dasar Awam Dalam Era Trnsformasi Ekonomi: Cabaran dan Halatuju” Johor Bahru, 7-9 Juni. 